pyrexia depends very much on its cause. Where it accompanies tuberculisation it probably will subside of itself when the tuberculous process quiesces, and even if persistent will only prevail in the afternoon. An effervescing saline, with a few drops of tincture of aconite or a few grains of quinine, is all that is then wanted. But pyrexia accompanying acute excavation, or acute excavation and tuberculisation, is very troublesome and sometimes quite intractable. Antipyretics, of which there are any number, according to my experience only give temporary relief, and often do harm by depressing the patient's constitutional powers and producing collapse. I have seen the temperature depressed from pyrexia to a subnormal reading by doses of antipyrin or phenacetin. but always with bad results, and after the use of the medicine has been omitted the temperature has risen as high as ever before. The great object in the treatment of this form of pyrexia is to keep the patient quiet in bed or lying on a coucb, and, if possible, in the open air, $\grave{a} l a$ Dettweiler; to feed him frequently; and to supply alcohol to repair tissue waste, while administering only sufficient antipyretics to keep the temperature within moderate bounds. Quinine in small doses in effervescence before the rise or during the rise of temperature will often suffice, or Henn's well-known pill twice a day. Anyone who studies the phenomena of fever knows that temperature rise is only a small portion of the process, and that by lowering the chart we do not get rid of the factors of heat production or of the wear and tear of the tissues, and so our best line is rather to keep up strength and weight by a frequent supply of food. The diarrbœa which accompanies tuberculous ulceration may be checked by sulphate of copper and opium if the ulcerative process be limited in extent, but if there is much ulceration, and it is the ileum and large intestine which are involved, injections are best. The enema opil of the British Pharmacopceia is Excellent under these conditions, but $I$ have seen a few of the most obstinate cases yield to large injections of linseed tea, which has a most soothing influence on the irritable ulcers.

\section{ON THE IMPROBABILITY OF A PARASITIC ORIGIN OF MALIGNANT DISEASE. ${ }^{1}$}

BY R. BARWELL, F.R.C S. ENG.,

CONSULTIYG SURGLON TO CHARIYG-CROSS HOSPITAL,

$$
\text { (Concluded from p. 679.) }
$$

THE considerations advanced in the last three papers describing some of the obstacles to a belief in the parasitic nature of cancer would, of course, fall to the ground if such parasites conld be found and demonstrated in every malignant tumour and in no other position, and if they could at the same time be proved to be not merely creatures invading and living in previousiy diseased tissue, but parasites which bad attacked a healthy part and converted its elements into malignant structare. Now certain observers have announced at various times during the last five or six years that they have, under high powers of the microscope, discovered, embedded in the cells of cancer, the particular coccidium, which they believed to be productive of malignancy. The somewhat curious history of these microscopic "finds" is of such interest in connexion with this subject that a short and condensed review of the last few years' work must be given. Malassez ${ }^{2}$ in 1889 was, 1 believe, the first to strike the note of these alleged discoveries; he was closely followed by Albarran ${ }^{3}$ and Thoma. ${ }^{*}$ In 1890 Sjobring ${ }^{5}$ and Russell ${ }^{6}$ found certain bodies they described as the causal parasites of cancer. About eighteen months later Sondakewitch, ${ }^{7}$ Podwysozki, ${ }^{8}$ and Sawtchenko, ${ }^{9}$ afterwards Foa, ${ }^{10}$ Adamkiewicz, ${ }^{11}$ Cattle of Nottingham, ${ }^{12}$ L. Pfeiffer, ${ }^{13}$ and Jackson Clarke, ${ }^{14}$ have all described the alleged specific parasite. Dr. Korotneff, indeed, has not only

1 The previous papers appeared in THE LANCET of July 28th, Aug. 25th, and Sept. $22 \mathrm{nd}, 1894$

3 Comptes Rendus de la Société de Biologie, 1889.

5 lbin 1890.4 Fortschritte der Medicin, 1889.

Amnales de l'Institut de Pasteur, $1892 . \quad 8$ Tbid.

9 Centralblatt für Pathol., Anat., \&c., 1892.

11 Brit. Med. Jour., vol. i. 1893.

12 Brit. Ned. Jour., 1393, and Journal of Pathology and Bacteriology, 8894

is Lintersuchungen über den Krebs, und Zeitschrift für Hygiene, vol. iv. described but figured what looks in his plates a very large creature. which be names "rhopalocephalus carcinomatosus." 15 More important than these are the observations of Messrs. Ruffer, Walker, and Plimmer, ${ }^{16}$ of which more must by-and-bye be said. Some of the above-named have gone even further, claiming to have found the young of coccidia-that is to say, the falciform bodies which are the result--in quantity, the almost innumerable result-of one method in which the rabbit's coccidium oviforme generates. All this amounts to very strong evidence, the observers being all highly competent microscopists inspired with the greatest love of science and gifted with vast power of work. But the subject is fraught with very great difficulties. Such varieties of cell generation, endogenous by fission and mitosis, all frequently altered from the normal type, also many sorts of anomalous cell degenerations, invaginations, inclusions, aspects of partially completed phagocytosis, hypertrophy with chromatin changes of nuclei, and many other phenomena, occur so abundantly in cancer, especially if quickly growing, that the comprehension of many things that appear in the field of the microscope is exceedingly difficult, and often each one of several interpretations is open to many objections and various causes of doubt. Thus, some of the more cautious workers, like Steinhaus, ${ }^{17}$ after describing certain appearances, have carefully avoided giving any opinion, at least at first, though a year later that scientist positively denies their relationship to parasites. ${ }^{18}$ Others-for instance, MM. Borrel. ${ }^{9}$ Duplay, ${ }^{19}$ Cazin, ${ }^{19}$ Cornil, ${ }^{90}$ Fabre Domerque. ${ }^{19}$ Le Dentn, ${ }^{19}$ and others in France Klebs, ${ }^{21}$ Stroebe ${ }^{23}$ Schutz, ${ }^{23}$ Ribbert, ${ }^{24}$ Noeggerath, ${ }^{25}$ and Virchow, ${ }^{26}$ in Germany; Ballance, Shattock, ${ }^{27}$ Sheridan, Delépine, ${ }^{28}$ and more, in Fingland; and Welch ${ }^{29}$ in Americabave refuted, some, the whole of the contention that the peculiar bodies found in cancer are parasitic, while others have fixed their attention on certain supposed finds, pointing them out as erroneous. Thus Russell's fuchsine bodies, Wickham and Darrier's psorosperms in Paget's disease, the supposed crescentic spores-in fact, every assertion, perhaps with one exception," as to parasitic life made by different observers, has been shortly afterwards ascribed by other not less skilled scientists to degenerations, keratosis, cell inclusions, \&c. Even Metchnikoff, the eminent zoologist, whose leaning is decidedly towards the parasitism of cancer, asserts that the bodies seen by Soudakewitch, Podwyszoski, Stroebe, and Sawt schenko, and supposed by them to be the falciform spores of a sporozoon, are not really such, but are due to "chromatic degeneration of nuclei"; and, he adds, "they may be designated as pseudo-crescents, just as in cancers it is necessary to distinguish psendo-coccidia so often confounded with formations really analogous to sporozoaria." s0 Dr. Sims Woodhead, whose scientific care and knowledge are indisputable, seems to bave been led at one time to accept certain appearances shown by $\mathbf{M r}$. Jackson Clarke $^{31}$ as the spores of coccidia, but to have subsequently seen sufficient cause to withdraw this assent and to state that those objects were degenerated nuclei.

The exception above referred to as an allegation perbaps not yet contradicted is contained in the very important papers of Ruffer, Walker, and Plimmer. ${ }^{32}$ These scientists begin by denying the parasitic signification of many previous "finds" believed by the observers to be coccidia, and by very restricted acceptance of some others. They then describe their own discovery in many carcinomata of certain bodies, which they take to be the sporozoa producing cancer, and which they frequently speak of undoubtingly as "the parasite." Certainly their contention gains great support when such authorities as Professor Metchnikoff and Dr. Sims Woodhead endorse the writers' views. Yet it may be submitted that something 15 Sporozoen als Krankheitserreger, von Dr. Alexis Korotneff.
Berlin, 1893.

16 Papers in Journal of Pathology and Bacteriology.
17 Virchow's Archiv, vol. cxxvi.

20 Journal de l'Ana Médicale, 1891.

21 Journal de l'Anat. et de Phys., 1891

22 Beiträige zur Pathol. Anat., 1891.

23 Münchener Med. Wochenschrift, 1890

24 Deutsche Med. Wochenschrift, 1891.

25 Bemerk. über Carcinom-Einschi., 1892

26 Virchow's Archiv, 1892 : Note to Steinhaus' paper.

28 Transactions of the Pathol. Med. Jour., 1891.

Hrane Pathological Society and International Congress

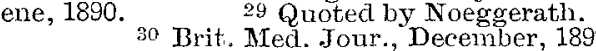

31 Pathological Society, TEE LANCET, March ilth, 1893.

32 Journal of Pathology and Bacteriology, vols. $i$. and $i_{*}$; and Transactions of the Pathological Society. 
more than mere authoritative averment is required-some reason for such judgment, some indication as to what special quality distinguishes these little cells from many others, almost or quite identical, which from time to time have with equal assurance been erroneously described as "the cancer parasite." It is impossible to look at the plates illustrating the lapers of Armand Ruffer and his collaborators without being struck by their great beauty; indeed, they form a sort of epoch in the art of representing histological and pathological sections, fixed, hardened, and stained in the newest manner. In the letterpress many directions are given as to the best way for the purpose of carrying out these procedures, for Armand Ruffer rightly says : "In all scientific questions the methods used are of the greatest importance, for a great deal in the recognition of these parasites depends on their staining reactions. "33 Nevertheless, their method, for instance, of hardening and of fixing was at one time "absolute alcohol, chiefly used for hardening. No advantage appeared to result from the use of sublimate." 34 Afterwards, "Given np alcohol because uncertain." 3a And used "concentrated aqueous solution of sublimate." 36 Fet the absolute conviction of finding the protozoon of malignancy is equal in all cases. The staining reactions of these bodies appear to be the only test relied on; it will have been noted that in a quotation from Professor Metchnikoff the word "pseudo-coccidia" was used, a term which shows that there are in cancers certain bodies so extremely like true coccidia as to be véry easily mistaken. Ruffer and Plimmer give in the very beautiful plates above mentioned drawings of what they deem pseudo and of what they call true coccidia. The only difference, according to the plates and description, is a slight, very slight, variation in the staining. Fig. $3^{37}$ and Fig. 51 both represent egg-shaped bodies within a cell, the shading of rotundity being beautifally given : the one, a little more stained than the other with hæmatoxylin and cochineal, has a slightly granular yellow mucleus (Fig. 3) ; the other has, in addition, a nucleolus which has responded to the hrematoxylin (Fig. 51). The one is described as "the parasite," the other as "an invaginated cell identical with the parasite of Wickham.' The reality, the reliability, of such distinction depends, therefore, on whether such slight difference in staining may be accepted as the one sole and sufficient witness. The manner in which animal cells of whatever kind accept different dyes very much depends on the mode and amount of their degeneration: those affected with keratosis react differently to those undergoing fatty changes or degradation of chromatin, decay of mucleus or nucleolus. Other more subtle changes seem to have an influence even larger than in the examples just cited-an influence, for instance (to refer again to the excellent plates) which absolutely changes the colour produced by the same treatment and dye. Thus, Figs. 1 to $5^{38}$ are from a cancer of the stomach all hardened in alcohol and dyed with Ehrilch-Bionde stain. The general protoplasm of the cells, called by the writers "parasites," is blue in all ; but let this be noted: the nucleus of all is rather dark-red. Figs. 7, 8, and 9 are also from a cancer of the stomach, hardened and stained as above. Now the nucleus of the first is blue, those of the other two are very light red. It might be supposed that too deep staining of Fig. 7 caused this difference, if Fig. 16 were left out of connt. That figure is described as "two cancer cells joined together and distended by four huge parasites- $c, b, c, d$, nuclei of parasites" ; $a$ is light blue, $b$ and $c$ are dark blue, $d$ is red. ${ }^{39}$ Thas staining with one and the same reagent has on these bodies very different effects even in one and the same section. How, then, can so slight a difference--such, for instance, as that described in Figs. 3 and 51 of the later paper-be accepted as the distinguishing mark between a coccidium and an invaginated or keratosed cell? Surely before accepting these things decisively as "parasites" something more distinctive is wanted, especially as so many false trails have already been struck, as so many eminent histologists are highly sceptical, and as there was publicly made such a statement as this: "The other day he (Dr. Sims Woodhead) had received a note

33 Transactions of the Pathological Society, vol. liv,, pp. 210, 211.

it Journal of Pathology and Bacteriology, vol. i., p. 203 . 25 Transactions of the Patholog.

35 Juurnal of Pathology and Bacteriolety, rol. liv., p. 210 $3 *$ Ibia., vol. i., p. 198 .

39 The nucleus $b$ is peculiar in form also. and a paper from Mr. Gustav Mann, assistant to the Professor of Physiology in the University of Edinburgh, certainly an expert in the preparation of histological specimens, both vegetable and animal, who pointed out that he had been able to demonstrate in many of his specimens nuclei which he could not distinguish from the parasitic protozoa of epithelial cells as described by Ruffer, Walker, and Galloway." 40 Moreover, in a case of fibrous thickening of the subperitoneal tissue, a thickening which he especially points out to be inflammatory and non-malignant, Jr. Hebb found, described, and figured bodies which are, as he says, identical with the "cancer parasites."

Still more antagonistic to the parasitic nature of these bodies is the fact that spores have never been seen. It has already been stated that the bodies described as such by Soudakewitch and some others (falciform bodies) are by Metchnikoff declared to be degenerated nuclei. The shuttleshaped spores (pseudo-navicellæ) so frequent in sporozoic infection of animals have never been seen in cancer tissue. It has been endeavoured to account for this by supposing that the young of this supposed creature are formed elsewhere. If so, the life history is different to that of all those parasitic sporozoa which we know. In all these the spores are formed within the host, and the young after reaching a certain stage may leave their nursery habitat and complete their growth elsewhere. Thus, wherever sporozoa are really found, multitudes of the infant form and of the fecund prolific parents abound. Not so in carcinoma; every supposed find of psorosperms has been negatived. ${ }^{41}$ Ruffer and Plimmer have indeed described "the phenomena of division of these parasites," but those phenomena differ in nowise from the direct division of tissue cells, while they are in many ways unlike what is observed in coccidian propagation. Moreover, the results of that described division are two globnlar or oval bodies, which is not the form under which young sporozoa seek and invade fresh hosts. Such could find no habitat The bodies are unlike coccidia in everything except their form, and this they have in common with a hundred other simple cells. Such a creature, without movement and without progeny formed and completed within the tissue or organ, could not possibly invade large districts and constitute or produce an infiltrating neoplasm.

Here both time and space warn me to conclude; but because these four papers have been somewhat scattered I would wish to summarise the conclusions to which they point-viz.: However plausible be the analogies which some have sought to establish between carcinoma and the infectious grannlomata; however probable the parasitic origin of malignancy may at first sight seem ; yet closer investigation shows that those analogies are illusory, and that clinical, experimental, biological, and microscopic research all tend to and ultimately do lead away from that hypothesis, and towards its disproof. I would also point out that I have refrained from alluding to $m y$ own investigations and experiments, because the former wonld be quite as open to doubt as those of the authorities above named. The latter, like those of Messrs. Ballance and Shattock, have had uniformly negative results; I have therefore preferred, rather than bear witness, to sum up the evidence.

Wimpole-street, W.

\section{ON THE OCCURRENCE OF DIPHTHERITIC PARALYSIS WITHOUT PREVIOUS FAUCIAL AFFECTION.}

BY LEONARD G. GUTHRIE, M.D., M.R.C.P.LOND., ASSISTANT PHYSICIAY T'O THE CHILDREY'S HOSPITAL, PADDINGTON-
GREEN; THE NORTH-WEST LONDON HOSPITAL; AND THE HOSPITAL FOR EPIIEPSY AND PARALYSIS, REGENT'S-PARK.

Tнस experiments of Dr. Sidney Martin ${ }^{\mathrm{I}}$ prove beyond doubt that diphtheritic paralysis may be induced in animals by inoculation sub cutem of certain diphtherial products. Hence the belief that paralysis only follows diphtheria when the fauces have been affected is clearly a pathological heresy. Yet it must be admitted that clinical evidence is not so

40 Dr. Sims Woothead's remarks at the postponed discussion at the Pathological Society, March 7th, 1893

Pathological Society, Mareh 7th, 1893. 41 Pathological Society, March 7th, 1893.

1 Goulstonian Lectures on the Chemical Pathology of Diphtheria compared with that of Anthrax, Infective Endocarditis, and Tetmus. 